\title{
Review of Empirical Research on Foreign Language Teachers' Intercultural Teaching Beliefs from the Perspectives of Participants and Methods
}

\author{
Fenghua $\mathrm{Hu}^{1}$, Xiaoqiu $\mathrm{Fu}^{2 *}$
}

\author{
${ }^{1}$ Postgraudate student of the School of Foreign Studies, Yangtze University, Hubei, P.R. China. \\ ${ }^{2}$ Associate professor of the School of Foreign Studies, Yangtze University, Hubei, P.R. China. \\ *Corresponding Author
}

Received: 8 Oct 2020; Received in revised form: 19 Nov 2020; Accepted: 29 Nov 2020; Available online: 07 Dec 2020 C2020 The Author(s). Published by The Shillonga Publication. This is an open access article under the CC BY license (https://creativecommons.org/licenses/by/4.0/).

\begin{abstract}
In recent years, the topic of language teachers' intercultural teaching beliefs has attracted considerable research interest. This paper sampled 15 empirical research articles related to foreign language teachers' intercultural teaching beliefs. Through summarizing and analyzing the main research participants and methods of these studies, the review found that there are some limitations in the research participants and methods. Firstly, from the perspective of the research participants, these studies lay emphasis on middle school English teachers, and few studies take into account teaching experience and teaching environment factors. Then, from the perspective of research methods, this review found that most of the empirical studies are mainly conducted in quantitative methods and some research samples are too small to draw convincing conclusions. What's more, there are also some limitations on research instruments. In light of these findings, areas for further research are suggested.
\end{abstract}

Keywords - teachers'beliefs, intercultural language teaching, participants, methods.

\section{INTRODUCTION}

One of the most important changes in language learning and teaching over the past few decades has been the recognition of the cultural dimension as a key component. As early as the 1980s, our foreign language community realized the importance of cultural learning in foreign language teaching (Zhang, 2007). Since 2000, the national foreign language teaching syllabus and curriculum standards have begun to stress the goal of developing students' intercultural communicative competence, which has raised extensive discussions and research on foreign language teaching in academia (Kong \& Luan, 2012; Hu, 2013; Navarro, 2018). As the main participant of teaching activities, foreign language teachers hold different views on intercultural communication competence, and their beliefs in intercultural foreign language teaching are also diverse. In recent years, the majority of studies focuses on 
the current environment and development of intercultural communicative competence of foreign language learners at home and abroad (Xu, 2000; Byram \& Feng, 2004; Peter et al., 2015; Ge \& Wang, 2016). However, few studies have focused on foreign language teachers' intercultural teaching beliefs, and one issue with most of these studies is that the selection of research participants and methods has certain limitations.

The review aims to investigate the limitations of these 15 studies from the perspective of research participants and methods. From the perspective of the research participants, these studies lay emphasis on middle school English teachers, and some studies do not take into account the teaching experience, environment factors. From the perspective of research methods, these empirical studies are mainly quantitative research, and some research samples are too small to draw convictive results, and the research process needs to be improved. In light of these findings, future directions for the research of teachers' intercultural teaching beliefs are suggested.

\section{BACKGROUND}

\section{Intercultural communicative competence}

The United States is the first country in the world to start studying intercultural communication. In 1959, the book The Silent Language was published. Its author Edward Hall was called "the father of intercultural communication". Since then, the study of intercultural communication has officially started. For a long time, how to define intercultural communicative competence has been a hot topic in foreign language circles. Chinese and foreign experts and scholars have explored this concept from different angles according to their own research needs.

Meyer(1991) pointed out that intercultural communicative competence refers to "the ability of a person to behave adequately in a flexible manner when confronted with actions, attitudes and expectations of representatives of foreign cultures"(p.138). Byram's (1997) model of intercultural communicative competence identifies five different factors involved: Knowledge,
Attitudes, Skills of interpreting and relating, Skills of discovery and interaction and political education including critical cultural awareness. In all of these factors, critical cultural awareness which is defined as the ability to evaluate critically the perspectives and practices in other cultures and one's own is the most important content and the core of the ICC model.

\section{Teachers'beliefs}

Social constructivism emphasizes the dual role of the individual and the social and cultural environment in the construction of knowledge. Teachers, as learners of teaching, their teaching beliefs are the product of the gradual construction of the teacher's individual interaction with the environment. Prior education, personality characteristics, emotions and continuous and the changing teaching environment affect the formation and development of teachers' beliefs.

Although definitions of teachers' beliefs vary, the term is generally used to refer to teachers' pedagogic beliefs which teachers hold consciously or unconsciously. It is including teachers' views on classroom teaching, language learning, teacher roles, curriculum reform, and teacher professionalization (Borg, 2001) Williams\&Burden (1997) believed that teacher beliefs include teachers' personal knowledge and professional knowledge. It is generally accepted that teachers' beliefs provide a basis for action (Borg, 2011) and that beliefs affect and guide teachers' decision making (Isikoglu et al., 2009) Thus it can be seen that teachers' beliefs and teaching behaviors are closely related (Lou \& Liao, 2005).

\section{ILT}

ILT was developed by Byram(1997). He sought to address CLT's shortcomings with respect to the role of culture in language education, culture's relationship with language, and the influences of students' cultural backgrounds. In ILT, teachers need to be acquainted with basic insights from cultural anthropology, culture learning theory and intercultural communication. What's more, teachers should integrate ICC teaching into foreign language education (Edelhoff, 1993). So, teachers' ability to select effective teaching techniques and resources 
aiming to develop their learners' ICC in ILT is dependent on their understanding of the notion of ICC(Czura, 2016).

The most distinctive feature of intercultural foreign language teaching is to highlight the humanity of foreign language education: the overall goal of teaching includes not only the language and literature goals of improving learners' foreign language communication skills, but also the social and humanistic goals of improving learners' intercultural communication skills; improving foreign language communication skills, and it is also the foundation and prerequisite, and an important means of cultivating intercultural communication skills. The cultivation of intercultural communication skills also promotes the improvement of foreign language communication skills.

\section{REVIEW METHODS}

\section{Scoping}

A set of criteria was used to identify studies for the review. In order to review not only Chinese but also abroad empirical research on foreign language teachers' intercultural teaching beliefs, CNKI, Springer, and Elsevier databases were searched for journals written in
English and Chinese. What's more, to ensure the timeliness of the journals, all of these studies were published between 2005 and 2018.The studies were empirical, included the string of keywords: "intercultural teaching beliefs", "intercultural teaching beliefs", “teachers' cognition on intercultural teaching", "teachers' beliefs" and so on. Finally, 15 works were identified for the review.

\section{Data Analysis}

And then, grounded approach was employed to analyze and synthesis the findings of the selected journals. Firstly, research method, participants, main findings and arguments from each study were extracted and given respective codes. Then, based on the similarities and relevance of these studies, this paper lay emphasis on the research participants and methods. Eventually, limitations of the research participants and methods were identified.

\section{FINDINGS AND DISCUSSION}

The participants and methods of these 15 empirical studies of foreign language teachers' intercultural teaching beliefs are presented in Table 1.

Table.1: Research participants and methods of foreign language teachers' intercultural teaching beliefs

\begin{tabular}{|c|c|c|c|c|}
\hline AUT & $\begin{array}{c}\text { YEAR } \\
\mathrm{S}\end{array}$ & CH TOPIC & $\begin{array}{c}\text { RESEARCH } \\
\text { PARTICIPANTS }\end{array}$ & $\begin{array}{l}\text { RESEARCH } \\
\text { METHODS }\end{array}$ \\
\hline Sercu et al. & 2005 & $\begin{array}{l}\text { Foreign language } \\
\text { teachers' intercultural } \\
\text { teaching beliefs }\end{array}$ & $\begin{array}{l}424 \text { foreign language teachers from } 7 \text { countries, } \\
\text { middle school: } 66.6 \% \text {, vocational or art school: } \\
33.4 \% \text {, English teachers: } 79 \% \text {, German, French, } \\
\text { Spanish and other teachers: } 21 \% \text {, The average } \\
\text { teaching experience: } 35 \text { years }\end{array}$ & $\begin{array}{c}\text { Questionnair } \\
\text { e }\end{array}$ \\
\hline Dou Yan & 2005 & $\begin{array}{l}\text { Teaching beliefs and } \\
\text { practices of college } \\
\text { English teachers }\end{array}$ & $\begin{array}{l}84 \text { college English teachers from universities in } \\
\text { southern China, teaching experience less than } 5 \\
\text { years: } 39 \% \text {, 6-10 years: } 33 \% \text {, more than } 10 \text { years: } \\
28 \%\end{array}$ & $\begin{array}{c}\text { Questionnair } \\
\text { e }\end{array}$ \\
\hline $\begin{array}{c}\text { Derin ATAY } \\
\text { et al. }\end{array}$ & 2009 & $\begin{array}{l}\text { Turkish teachers of } \\
\text { English on intercultural } \\
\text { competence teaching }\end{array}$ & $\begin{array}{l}503 \text { primary, secondary and university English } \\
\text { teachers in different regions of Turkey, teaching } \\
\text { experience: } 1-5 \text { years: } 39 \%, 11-15 \text { years: } 12 \%, 16-20\end{array}$ & $\begin{array}{c}\text { Questionnair } \\
\text { e }\end{array}$ \\
\hline
\end{tabular}




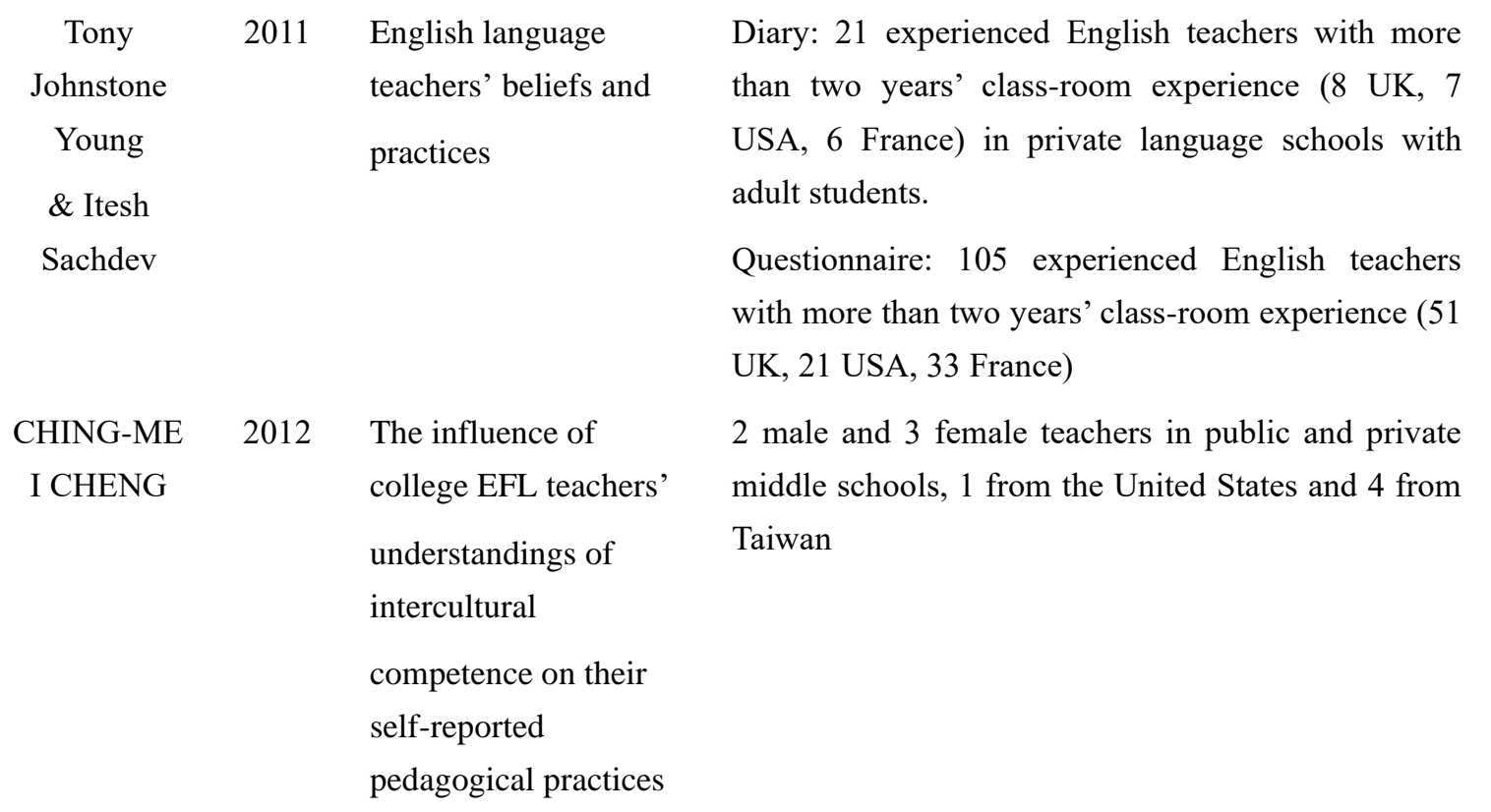

Scott P. 2012 The Beliefs of Foreign

222 American foreign language teacher, middle

Questionnair

Kissau Language Teachers

school: $53 \%$; primary school: $47 \%$, Spanish: $66.6 \%$, e\& Interview

French, German, Chinese: 33.4\% , teaching experience less than 5 years: $45 \%, 5-10$ years: $19 \%$, more than 10 years: $36 \%$

\begin{tabular}{|c|c|c|}
\hline $\begin{array}{l}\text { Chen } \\
\text { Guiqin }\end{array}$ & 2013 & $\begin{array}{l}\text { Problems in } \\
\text { intercultural Teaching } \\
\text { of college English }\end{array}$ \\
\hline $\begin{array}{c}\text { Han } \\
\text { Xiaohui }\end{array}$ & 2014 & $\begin{array}{l}\text { Current environment of } \\
\text { intercultural Training } \\
\text { of College Students }\end{array}$ \\
\hline $\begin{array}{l}\text { Paloma } \\
\text { Castro }\end{array}$ & 2014 & $\begin{array}{l}\text { Spanish teachers' } \\
\text { intercultural teaching } \\
\text { beliefs }\end{array}$ \\
\hline $\begin{array}{l}\text { Scott P. } \\
\text { Kissau; } \\
\text { Marion }\end{array}$ & 2014 & $\begin{array}{l}\text { An international } \\
\text { comparison of teacher } \\
\text { beliefs }\end{array}$ \\
\hline $\begin{array}{l}\text { Rodgers; } \\
\text { Helga } \\
\text { Haudeck }\end{array}$ & & \\
\hline Zhang Chun & 2014 & $\begin{array}{l}\text { College English } \\
\text { teachers' intercultural } \\
\text { teaching beliefs }\end{array}$ \\
\hline
\end{tabular}

36 college English teachers and 101 Non-English major students (Engineering: 57, Science: 44), age: $30-35$ years old: $61.11 \%, 36-40$ years old: $22.22 \%$,

1081 teachers in 39 universities; English major: $66.6 \%$, Non-English major: $33.4 \%$

Questionnair e \& Diaries

Interview

Questionnair e

Questionnair e 35 Spanish middle school English teachers, The average teaching experience: 11.4 years

Questionnair e

136 American teachers (Spanish: 61\%, French, Questionnair German, Japanese: 39\%, middle school: 57\%, e\& Interview Primary school: $43 \%$ ) and 118 German pre-service teachers

201 College English teachers from Wu Han; 127

Questionnair teaching in non-English schools, 74 teaching in e English school; $8.1 \%$ has a doctoral degree, $32.4 \%$ has overseas study experience 


\begin{tabular}{|c|c|c|c|c|}
\hline Anna Czura & 2016 & $\begin{array}{l}\text { Student teachers' } \\
\text { views on intercultural } \\
\text { communicative } \\
\text { competence }\end{array}$ & $\begin{array}{l}162 \text { normal students of three majors ( English: } \\
45.7 \% \text {, German: } 27.7 \% \text {, History: } 26.6 \% \text { ), and these } \\
\text { students will teach in primary and lower secondary } \\
\text { schools }\end{array}$ & $\begin{array}{c}\text { Questionnair } \\
\mathrm{e}\end{array}$ \\
\hline Anna Czura & 2017 & $\begin{array}{l}\text { Students Teachers' } \\
\text { Beliefs About } \\
\text { Developing } \\
\text { Intercultural } \\
\text { Communicative } \\
\text { Competence }\end{array}$ & $\begin{array}{l}74 \text { undergraduate students ( } 2 \text { Eastern Europe; } 72 \\
\text { Polish) of English at a University in the south of } \\
\text { Poland, } 60 \text { female and } 14 \text { male students aged } 21-23 \text {, } \\
\text { and these students will teach in primary and lower } \\
\text { secondary schools }\end{array}$ & $\begin{array}{c}\text { Questionnair } \\
\mathrm{e}\end{array}$ \\
\hline $\begin{array}{l}\text { Jo Oranje \& } \\
\text { Lisa F } \\
\text { Smith }\end{array}$ & 2018 & $\begin{array}{l}\text { The extent to which } \\
\text { New Zealand language } \\
\text { teachers' beliefs and } \\
\text { practices are aligned } \\
\text { with intercultural } \\
\text { language teaching }\end{array}$ & $\begin{array}{l}76 \text { middle school teachers in South New Zealand, } \\
\text { French: } 34.2 \% \text {, Japanese: } 17.1 \% \text {, English: } 10.5 \% \text {; } \\
\text { The average teaching experience: } 15.7 \text { years, } \\
\text { teaching experience from } 40 \text { to } 49 \text { years: } 31.6 \%\end{array}$ & $\begin{array}{c}\text { Questionnair } \\
\mathrm{e}\end{array}$ \\
\hline $\begin{array}{l}\text { Ni Ling \& } \\
\text { Zhang Yun }\end{array}$ & 2018 & $\begin{array}{l}\text { The relationship } \\
\text { between English } \\
\text { teachers' teaching } \\
\text { beliefs and practices }\end{array}$ & $\begin{array}{l}4 \text { skilled primary school English teachers in Beijing, } \\
\text { The average teaching experience: over } 10 \text { years }\end{array}$ & $\begin{array}{l}\text { Interview \& } \\
\text { Classroom } \\
\text { observation }\end{array}$ \\
\hline
\end{tabular}

\section{Participants}

First, the empirical research participants cover pre-service teachers, novice teachers and experienced teachers from elementary school to university. Overall, there are 9 empirical studies' participants are middle school teachers, accounting for $60 \%$, and 6 studies focused on college teachers, accounting for $40 \%$ (but here, it must be pointed out that part of the research participants include foreign language teachers in elementary schools, middle schools, and colleges). But in general, the review found that teachers in college and middle school are the main research participants in these studies. Relatively speaking, few studies focused on the foreign language teachers' in primary, vocational and art school, because there is only 1 study that focused on primary school teachers and 1 study have taken foreign language teachers in vocational and art school as main participants. However, it should be noted that foreign language teachers from different school may have different intercultural teaching beliefs, so this factor needs to be taken into consideration.

Then, a number of studies did not take the schools where teacher works into consideration when selecting research participants. For example, When surveying Turkish English teachers' intercultural teaching beliefs and the extent to which Turkish English teachers' beliefs are aligned with actual classroom teaching behaviors, ATAY selected participants from three kinds of schools: primary schools, middle schools and universities across Turkey. And there is another example, Sercu selected foreign language teachers from different schools when studying the relationship between foreign language teachers' intercultural teaching beliefs and teaching practice, such as primary school, vocational and technical schools and art schools. However, teachers in different schools and classrooms may hold different beliefs. At the same time, Yang(2018) pointed out that different regions or schools 
have different speeds in updating teaching concepts. Therefore, in the future study, teaching environment should also be taken into consideration.

Furthermore, some empirical studies did not take into account the teaching experience of foreign language teachers when selecting the research participants. For example, when investigating whether foreign language teachers in different countries hold the same beliefs in intercultural foreign language teaching, Kissau et al. (2014) selected in-service teachers with rich teaching experience from middle schools and primary schools in USA, but the selection of samples in Germany is limited to pre-service teachers who have no teaching experience in foreign language teaching. Another study (Cheng, 2012) investigated Taiwan teachers' understanding of intercultural competence in English teaching and how their understanding affects their classroom practice, among the five interviewees selected, the longest teaching experience is 37 years, the shortest one is only 7 years. A study by Castro et al. (2004) surveyed Spanish teachers' beliefs in intercultural teaching, among the participants selected, the longest teaching experience was 26 years, and the shortest was only 2 years. Basturkmen (2012: 288) pointed out: "More experienced teachers are likely to have more experientially informed beliefs than relative novices, or inexperienced teachers". However, because in above empirical research, the research purposes were not to examine whether the intercultural teaching beliefs held by teachers with different teaching experience were different or not. Therefore, considering the rigor of the research, researcher should control the variable of teaching experience when selecting research participants.

\section{Methods}

First of all, most of the empirical studies into foreign language teachers' intercultural teaching beliefs were broadly based on quantitative research methods. Among 15 studies, there are 10 studies were conducted in a single quantitative research method, mixed research methods are adopted in only 3 studies and these 3 empirical studies are mainly based on questionnaire surveys. However, Xiang et al. (2016) pointed out that teacher belief research needs to capture invisible and intangible hidden content. What's more, the actual intercultural teaching beliefs may not be completely consistent with the teaching beliefs stated in questionnaires or interviews, so the final survey results may be somewhat different from the real results. And, it is important to note that teacher beliefs belong to invisible and intangible hidden content (Xiang et al., 2016), so in terms of this issue, qualitative method will be the best choice.

Secondly, research sample size of many studies is too small, so the conclusions drawn may not very convincing. For example, Cheng (2012) only selected five interview participants when investigating the influence of college EFL teachers' understandings of intercultural competence on their self-reported pedagogical practices. Furthermore, when Sercu (2014) investigated the relationship between international teachers' intercultural teaching beliefs and teaching practices, he selected teachers from seven countries, the largest sample size was 151, however, the smallest sample was only 30. That is to say, the conclusions may be too far-fetched, if the sample size is enlarged, different or even opposite conclusions may be drawn.

Thirdly, the actual intercultural teaching beliefs of teachers may not be completely consistent with the teaching beliefs stated in questionnaires or interviews (Klein, 2004), so the final survey results may be somewhat different from the real results. For example, when Young(2011) exploring English language teachers' intercultural teaching beliefs and practices, the diaries data written by teachers were reported by teachers themselves rather than collected and draw on actual diary by author directly. Then, this review found that almost all of the above empirical studies used questionnaire surveys or interviews when investigating teachers' intercultural teaching beliefs. So, the results obtained were all from teachers' self-reports, and no other data were obtained as a verification, such as students' feedback, teaching plans, etc.

Finally, some empirical research participants come from different countries and speak different languages, but some researchers did not translate the questionnaire into different languages. For example, in a study of foreign 
language teachers' beliefs in intercultural teaching in seven countries, because specific concepts are difficult to translate, Sercu's (2014) questionnaires are all in English without translation, but some research participants are not proficient in English and therefore, misunderstanding will be an unavoidable problem. For this reason, the beliefs reported by some research participants on the questionnaire may deviate from their true beliefs, which will affect the accuracy of the research findings.

\section{CONCLUSION AND IMPLICATIONS}

In general, the view found that there is not much studies on intercultural teaching beliefs of foreign language teachers at home and abroad, especially in China. Therefore, researchers can continue to carry out in-depth and systematic research, and research methods and participants need further attention in future research. At the same time, through summarizing and analyzing the research participants and methods of these studies, the review found that there are some limitations in research participants and methods.

To date most of the empirical research are mainly concentrated on in-service middle school and university teachers. Therefore, future research should lay more emphasis on foreign language teachers in primary, vocational and art schools. At the same time, considering the rigor of the research, teaching experience and teaching environment should also be taken into account. In addition, it is necessary to consider whether the sample size of the selected research participants is sufficient to support the conclusions obtained. So, the review suggests the need to enlarging research samples so as to draw more persuasive results.

Furthermore, most of the studies were broadly based on quantitative research methods. So, in the future, we would argue that mixed methods need to be adopted when verifying intercultural teaching beliefs stated by teachers. Finally, the current studies on foreign language teachers' intercultural teaching beliefs are mainly focused on teachers' stated beliefs or the comparison of teachers' beliefs and practice. So, further research are needed on teachers' intercultural teaching beliefs at different stages or in different time so as to investigate the changes of teachers' intercultural teaching beliefs.

While, the review also has some limitations. First of all, the selected studies are only 12 articles. On the one hand, there are few empirical studies on foreign language teachers' intercultural teaching beliefs. On the other hand, there may be some studies that have not been found. Secondly, in the selected research, the authors of some empirical studies did not describe the research participants and research methods very clearly, such as the studies by CHENG (2012) and Czura (2016). Therefore, the above limitations will affect the analysis and comparison of the research participants and research methods of this review to a certain extent.

\section{REFERENCES}

[1] Borg, M. Teachers' beliefs[J]. ELT Journal, 2001(02): 186-187.

[2] Borg, S. The impact of in-service education on language teachers' beliefs[J]. System, 2011(39), 370-380.

[3] Byram, M. \& Feng, A. Culture and language learning: Teaching, research and scholarship[J]. Language Teaching, 2004(03): 149-168.

[4] Byram, M. (1997). Teaching and assessing intercultural communicative competence. USA:Multilingual Matters, 1997.

[5] Castro, P.,Sercu, L.\& Garcia, M.C.M. Integrating language-and-culture teaching: an investigation of Spanish teachers' perceptions of the objectives of foreign language education[J]. Intercultural Education, 20104(01): 91-104.

[6] CHING-MEI CHING. The influence of college EFL teachers' understandings of intercultural competence on their self-reported pedagogical practices in Taiwan[J]. English Teaching: Practice and Critique, 2012(11): 164-182.

[7] Chun, Z. Quantitative research on the teacher knowledge of Chinese university EFL teachers_—Based on intercultural communication competence development[J].Foreign Languages in China, 2014,11(06):91-95+105. 
[8] Chunping, G\&Shouren, W. On cultivation of intercultural communicative competence in college English teaching $[\mathrm{J}]$. Foreign Languages and Their Teaching,2016(02):79-86+146.

[9] Czura, A. Major field of study and student teachers' views on intercultural communicative competence[J]. Language and Intercultural Communication, 2016(01): 83-98.

[10] Czura, A. Students Teachers' International Experience and Their Beliefs About Developing Intercultural Communicative Competence. In: Pawlak M., Mystkowska-Wiertelak A. (eds) Challenges of Second and Foreign Language Education in a Globalized World[M]. Second Language Learning and Teaching. Springer, Cham. DOI: org/10.1007/978-3-319-66975-5_19, 2018.

[11] Deliang, K\&Shuwen, L.Construction of modes for intercultural college English teaching — The status quo and theoretical reflection[J].Foreign Language World,2012(02):17-26.

[12] Derin ATAY. The role of intercultural competence in foreign language teaching[J]. Inonu University Journal of The Faculty of Education, 2009(03): 123-135.

[13] Edelhoff, C. English among the other European languages. In English language learning in Europe: issues, tasks and problems. Best of ELTECS, British Council 1995; ELTECS Conference, Bratislava,1993.

[14] Guiqin, C. An empirical study of college English intercultural teaching: problems and countermeasures_-Based on a case study of Heilongjiang University of science and technology[D].Shanghai International Studies University, 2014.

[15] Helen Basturkmen. Review of research into the correspondence between language teachers' stated beliefs and practices[J]. System, 2012(02): 282-295.

[16] Heying, L\&Fei, L.The Relationship between College English Teachers' Teaching Beliefs and Teaching Behaviors: Qualitative and Quantitative Analysis Research[J].Foreign Language Teaching and Research,2005(04):271-275.

[17] Hongling, Z.Intercultural foreign language teaching[M].Shanghai:Shanghai foreign language education press, 2007.

[18] Isikoglu, N., Basturk, R., Karaca, F. Assessing in-service teachers' instructional beliefs about student-centred education: a Turkish perspective[J]. Teaching and Teacher Education, 2009(2), 350-356.

[19] Junru, Y.English teachers and intercultural foreign language teaching_-A Review of empirical research $[\mathrm{J}]$.Overseas English,2018(01):74-75+77.

[20] Kissau, S. Foreign language teaching: an international comparison of teacher beliefs[J]. Research in Comparative and International Education, 2014(01): 227-242.

[21] Klein, F.M.V. Culture in the foreign language classroom: teachers' beliefs, opportunities and practice[D]. USA: University of Minnesota, 2004.

[22] Lisheng, X.On intercultural communicative competence[J].Foreign Languages and Their Teaching,2000(07):17-21.

[23] Ling, N\&Yun, Z.A case study on the relationship between teaching beliefs and teaching behaviors of primary English teachers[J].Primary School English Teaching and Learning, 2017(09):32-36.

[24] Maoying, $X$ et al.Retrospect and Reflection on the Research of Foreign Language Teachers' Beliefs__ Based on the Statistical Analysis of 6 Journals of Applied Linguistics(1990-2014)[J]. Foreign Language World,2016(01):79-86+95.

[25] Meyer, M. Developing transcultural competence: case studies of advanced foreign language learners. In D. Buttjes \& M. Byram (Eds.), Mediating languages and cultures[M]. USA: Multilingual Matters, 1991.

[26] Navarro, L. Book review[J]. System, 2018, 73: 97-99.

[27] Oranje, J. \& Smith,L.F. Language teacher cognitions and intercultural language teaching: The New Zealand perspective[J]. Language Teaching Research, 2018(03): 310-329.

[28] Peter, J. et.al. Language learning and intercultural communicative competence: An action research case study of learners of portuguese[J]. Procedia-Social and Behavioral Sciences, 2015, 200: 307-312.

[29] Scott P. Kissau, Bob Algozzine,Maria Yon. Similar but different: The beliefs of foreign language teachers[J]. Foreign Language Annals, 2014(04): 580-598.

[30] Sercu, L. et al.Foreign language teachers and intercultural competence[M]. UK:Cromwell Press, 2005. 
[31] Wenzhong, H. On the positioning of intercultural communication competence in China's foreign language teaching[J].Foreign Language World,2013(06):2-8.

[32] Williams, M. \& Burden, R. Psychology for language learners: a social constructivist approach[M].UK: Cambridge University Press, 1997.

[33] Xiaohui, H.Cultivating college students' intercultural communicative competence-From the perspective of college English teachers[J].Foreign Language Research,2014(03):106-110.

[34] Yan, D. A study on teachers' beliefs and teaching practice among foreign language teachers in Chinese universities[J].Foreign Language Learning Theory and Practice,2015(03):42-48+26+95.

[35] Young, T. J., \& Sachdev, I. Intercultural communicative competence: Exploring English language teachers' beliefs and practices[J]. Language Awareness, 2011(02), 81-98. 